\title{
Are Blood Cultures Useful in Patients with Skin and Soft Tissue Infections?
}

\author{
Deri ve Yumuşak Doku Enfeksiyonu Olan Hastalarda Kan Kültürü Yararlı mıdır?
}

\section{(D) ilkay BOZKURT}

Ondokuz Mayıs University Faculty of Medicine, Department of Infectious Diseases and Clinical Microbiology, Samsun, Turkey

\section{Abstract}

Introduction: Blood cultures are almost routinely performed in patients hospitalized with skin and soft tissue infections (SSTIs). The aim of this study was to evaluate the diagnostic importance of blood cultures in patients hospitalized with SSTIs.

Materials and Methods: A total of 205 patients with cellulitis who were admitted to the adult Infectious Diseases and Dermatology Clinics at Ondokuz Mayıs University Hospital between January 2010 and June 2016, were included in the study. Data (including demographics, clinical characteristics, outcomes, number of radiologic and laboratory studies) were collected from electronic medical records.

Results: Blood cultures and wound cultures were performed in 205 (100\%) and 61 (29.8\%) patients, respectively. Seven out of 205 (1.5\%) blood cultures and 29 out of $61(47.5 \%)$ wound cultures were positive $(\mathrm{p}<0.001)$. The positive blood cultures yielded beta-hemolytic streptococci $(\mathrm{n}=4)$, methicillin-sensitive Staphylococcus aureus $(\mathrm{n}=2)$ and Serratia marcescens $(\mathrm{n}=1)$. Methicillin-sensitive Staphylococcus aureus was isolated in 18 out of 61 (25.9\%) wound cultures. 94 (46.3\%) patients had a history of antibiotic use prior to hospitalization.

Conclusion: Blood culture has a limited diagnostic value in the management of SSTIs. Clinicians should avoid performing unnecessary blood cultures in patients with cellulitis because of a lack of benefit and no contribution to patient management.

Keywords: Blood culture, bacteremia, cellulitis, pharmacoeconomics, economics

\section{Öz}

Giriş: Deri ve yumuşak doku enfeksiyonu (DYDE) tanısı ile hastaneye yatırılan hastalarda kan kültürü neredeyse rutin olarak alınmaktadır. Bu çalışmada DYDE tanısı ile yatırılan hastalarda kan kültürünün tanısal öneminin değerlendirilmesi amaçlanmıştır.

Gereç ve Yöntem: Ocak 2010 ile Haziran 2016 tarihleri arasında selülit tanısı ile Ondokuz Mayıs Üniversitesi Hastanesi Enfeksiyon Hastalıkları ve Dermatoloji Kliniklerine yatırılan 205 hastanın verileri elektronik kayıt sisteminden tarandı. Toplanan veriler hastaların demografik verileri, klinik özellikleri, sonuçları ile radyoloji ve laboratuvar bulgularını içermekteydi.

Bulgular: Kan ve yara kültürü sırası ile $205(\% 100)$ ve $61(\% 29,8)$ hastadan alınmıştır. Kan kültürü alınan hastalardan sadece yedisi $(\% 1,5)$, yara

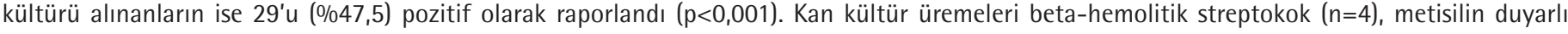
Staphylococcus aureus $(n=2)$ ve Serratia marcescens $(n=1)$ idi. Metisilin duyarlı Staphylococcus aureus 61 yara kültürünün 18'inden $(\% 25,9)$ izole edildi. Doksan dört $(\% 46,3)$ hastanın hastaneye yatışları öncesinde antibiyotik kullanım öyküsü bulunmaktaydı.

Sonuç: DYDE tanısında kan kültürünün tanısal değeri son derece sınırlıdır. Klinisyenler yararı olmayan ve hasta yönetimine katkısı olmayan gereksiz kan kültürü alımından kaçınmalıdır.

Anahtar Kelimeler: Kan kültürü, bakteremi, selülit, farmakoekonomi, ekonomi

\section{Introduction}

Skin and soft tissue infections (SSTIs) are commonly encountered diseases in clinical practice. Cellulitis has been defined as a bacterial infection of the dermis and subcutaneous tissue ${ }^{[1]}$. The etiological agents of the SSTIs generally remain unclear because clinicians do not need microbiological confirmation routinely for the diagnosis ${ }^{[2]}$. Staphylococcus aureus is the most common

Cite this article as: Bozkurt I. Are Blood Cultures Useful in Patients with Skin and Soft Tissue Infections? Mediterr J Infect Microb Antimicrob. 2018;7:6.

\footnotetext{
add Adress for Correspondence/Yazışma Adresi: İlkay Bozkurt MD, Ondokuz Mayıs University Faculty of Medicine, Department of Infectious Diseases and Clinical Microbiology, Samsun, Turkey

Phone: +90 3623121919 E-mail: drilkaybozkurt@gmail.com ORCID: orcid.org/0000-0002-8425-9719

Received/Geliş Tarihi: 15.08.2017 Accepted/Kabul Tarihi: 26.01.2018

๑Copyright 2018 by the Infectious Diseases and Clinical Microbiology Specialty Society of Turkey

Mediterranean Journal of Infection, Microbes and Antimicrobials published by Galenos Yayınevi.
}

Published: 29 January 2018 
cause of SSTIs ${ }^{[3]}$. Despite methicillin resistance has become increasingly common among $S$. aureus strains, methicillinsensitive S. aureus (MSSA) is a major problem in communityacquired SSTIs ${ }^{[4]}$. Blood cultures are almost routinely performed in patients admitted to hospital with SSTIs ${ }^{[5]}$. However recent guidelines do not recommend blood cultures, wound aspirates or swabs routinely in patients with SSTIs, particularly cellulitis ${ }^{[6]}$.

The main objective of this study was to describe the diagnostic importance of blood cultures in patients hospitalized with SSTIs.

\section{Materials and Methods}

This study was conducted in a tertiary-care university hospital with 1150 hospital beds. Ondokuz Mayıs University Hospital is one of the reference medical centers in the Black Sea region of Turkey. Medical records of patients who required hospitalization for SSTIs were retrospectively reviewed by using ICD-10 codes. The electronic database listed all the patients older than 18 years of age who required hospitalization for cellulitis between January 2010 and June 2016. Surgical site infections were not included. Patients were enrolled if at least one blood culture was obtained. Patients who had osteomyelitis or discharged from the emergency department were excluded. Patients with an initial diagnosis other than cellulitis prior to hospitalization were also excluded. We collected the data on patient's demographic characteristics, information on the presence of fever, antibiotic treatment before admission, recent antibiotic use (during the past one week), location of the wound, precipitating cause of infection, length of hospital stay, number of blood and wound/ pus cultures, culture results, surgical intervention, chronic diseases and other infections.

Patients meeting at least one of the following criteria were classified as having complicated SSTls: deep-seated infection requiring surgical intervention, presence of systemic symptoms (e.g. fever), presence of complicating co-morbidities, neutropenia, progression to tissue necrosis or existing necrotizing fasciitis, burns and bites ${ }^{[3,6]}$.

Blood culture specimens were routinely incubated in the BACTEC (Becton Dickinson, Sparks, MD) system up to 5 days. Cultures were defined as negative if there were no bacterial growth. Contamination was described if they grew coagulase-negative staphylococci (CNS), Corynebacterium spp., Bacillus spp., and Propionibacterium spp. and were defined as positive if culture results revealed any other microorganisms ${ }^{[7]}$. Abscess culture, deep tissue sample (surgical specimen) and exudates from skin lesions or pus were assessed as wound culture.

\section{Statistical Analysis}

The data were collected and recorded. IBM SPSS version 23 was used to analyze the data. The qualitative results were presented as frequency (\%) and quantitative results were presented as arithmetic mean \pm standard deviation (minimum-maximum). Blood and wound culture positivity were observed by twoproportion z-test. A $p$ value of less than 0.05 was considered statistically significant. The cost of blood culture kit was $2.6 \$$, positive growth without susceptibility was $7.3 \$$ and with susceptibility test cost was $12 \$$ per culture.

\section{Results}

During the 6-year period, the initial medical database search identified 816 patients who were admitted to the hospital with the diagnosis of cellulitis. Three-hundred and fifty two subjects whose blood cultures were not obtained, 245 patients without cellulitis on admission, six cases who were discharged from the emergency department, and eight patients with osteomyelitis were all excluded. Two-hundred five cases of complicated SSTIs were enrolled in this study.

Demographic and clinical characteristics of the patients and laboratory investigations are demonstrated in Table 1. The mean age was $58.1 \pm 15.6$ with a range of 18 to 91 years. $44.4 \%$ of the 205 patients were male. Ninety four $(45.9 \%)$ received at least one dose antibiotic prior to hospitalization yerine while 109 (53.2\%) had fever on admission.

A total of 463 blood cultures were obtained in the 205 patients and more than one blood culture was drawn from 108 patients. Seven had positive blood culture and contaminated in $21(10 \%)$. Beta-hemolytic streptococci $(n=4)$ was the frequent cause of bacteremia (Table 2). The patient with MSSA bacteremia was a 61-year-old male with an abscess surrounded by cellulitis in the gluteal region following an intramuscular injection.

Among the patients hospitalized due to cellulitis; 25 had abscess, 7 had bullous lesions and 7 progressed to necrotizing fasciitis. The most common risk factor for SSTIs was tinea pedis $(30.2 \%)$ (Table 3). The most frequent reason for presentation was lower extremity infections (71.7\%) (Table 1). Ultrasonography $(n=105)$ and plain X-ray $(n=80)$ were commonly performed. Ultrasonography was used in patients with abscess as an initial imaging modality except in four patients who underwent computed tomography (CT). Magnetic resonance imaging and CT were used to identify osteomyelitis in patients with diabetes $(11 / 64)$ or to determine abscess formation in patients in whom SSTI occurred after an intramuscular injection (4/7), and to differentiate necrotizing fasciitis (3/8).

Ninety four (45.9\%) patients had been pretreated with antibiotics or had a history of the use of at least one dose antibiotic effective against possible microorganisms. The antibiotic regimens initiated on admission are demonstrated in Table 1. Sequential therapy after initial intravenous antibiotics 
was implemented in our center. A wound culture was performed in $61(29.8 \%)$ patients and $29(47.5 \%)$ had a positive result. Cutaneous needle aspiration was not performed in any of the patients. Abscess culture was performed on admission in 25 patients. Seventeen deep tissue samples (surgical specimen), 19 exudates from skin lesions or pus were all obtained. The common microorganisms isolated from the wound cultures were: MSSA $(\mathrm{n}=18)$, Pseudomonas aeruginosa $(\mathrm{n}=3)$, and Klebsiella spp.

Table 1. Patient demographics, characteristics and laboratory investigations

\begin{tabular}{|c|c|}
\hline Characteristics & n (\%) N: 205 \\
\hline Gender (male) & $91(44.4)$ \\
\hline Age, years, mean \pm SD (median, min-max) & $58.1 \pm 15.6(60,18-91)$ \\
\hline $\begin{array}{l}\text { Chronic disease } \\
\text { Diabetes } \\
\text { Cancer/malignancy } \\
\text { Congestive heart failure } \\
\text { Chronic renal failure } \\
\text { Renal transplantation } \\
\text { Cerebrovascular disease } \\
\text { Others }\end{array}$ & $\begin{array}{l}120(58.5) \\
64(31.2) \\
22(10.7) \\
12(5.9) \\
7(3.4) \\
6(2.9) \\
6(2.9) \\
3(1.5)\end{array}$ \\
\hline Fever & $109(53.2)$ \\
\hline $\begin{array}{l}\text { Localization } \\
\text { Leg } \\
\text { Foot } \\
\text { Arm } \\
\text { Hand } \\
\text { Neck } \\
\text { Abdominal wall } \\
\text { Breast } \\
\text { Face } \\
\text { Buttocks } \\
\text { Genitals }\end{array}$ & $\begin{array}{l}110(53.7) \\
37(18) \\
26(12.7) \\
8(3.9) \\
5(2.4) \\
5(2.4) \\
4(2) \\
4(2) \\
4(2) \\
2(1)\end{array}$ \\
\hline Antibiotic history prior to hospitalization & $94(45.9)$ \\
\hline $\begin{array}{l}\text { Administered antibiotics after } \\
\text { hospitalization* } \\
\text { Ampicillin sulbactam } \\
\text { Teicoplanin } \\
\text { Piperacillintazobactam } \\
\text { Daptomycin } \\
\text { Cefepime } \\
\text { Cefazoline } \\
\text { Others }\end{array}$ & $\begin{array}{l}163(79.5) \\
17(8.3) \\
10(4.9) \\
4(2) \\
3(1.5) \\
2(1) \\
6(2.9)\end{array}$ \\
\hline $\begin{array}{l}\text { Obtaining blood culture prior to antibiotic } \\
\text { therapy }\end{array}$ & $144(70.2)$ \\
\hline Number of blood cultures mean \pm SD & $2.3 \pm 2.3$ \\
\hline Wound/abscess culture & $61(29.8)$ \\
\hline $\begin{array}{l}\text { Imaging } \\
\text { Ultrasound } \\
\text { X-ray } \\
\text { X-ray + ultrasound } \\
\text { X-ray + ultrasound + magnetic resonance } \\
\text { X-ray + magnetic resonance } \\
\text { X-ray + computerized tomography } \\
\end{array}$ & $\begin{array}{l}135(65.9) \\
55(26.8) \\
21(10.2) \\
37(18) \\
13(6.3) \\
5(2.4) \\
4(1.9) \\
\end{array}$ \\
\hline Incision and drainage & $30(14.6)$ \\
\hline $\begin{array}{l}\text { Length of stay mean } \pm \text { SD (median, min- } \\
\text { max) }\end{array}$ & $12.4 \pm 9.8(10,1-71)$ \\
\hline
\end{tabular}

SD: Standard deviation, min: Minimum, max: Maximum $(n=3)$ (Table 2). Seven out of 205 (1.5\%) blood cultures and 29 out of $61(47.5 \%)$ wound cultures were positive $(p<0.001)$. Blood culture was performed in all patients in whom wound culture was obtained. All blood cultures were obtained before wound cultures (0-5 days before). Among 61 patients in whom wound cultures were obtained, blood culture was positive in $3(4.9 \%)$, and contamination was detected in 10 (16.4\%). Positive wound culture was not accompanied by positive blood culture in any patient. Six (20.7\%) cultures were also resulted as contamination. According to the guidelines ${ }^{[6]}$, eight out of 205 cases had an indication for blood culture. In two out of seven $(25.6 \%)$ and five out of $29(17.2 \%)$ patients, treatments were changed according to blood culture and wound culture results subsequently $(p=0.539)$.

The median length of stay was 10 days. None of the patients died and all were discharged following recovery except two. These two patients were transferred to another facility on their own request. Antibiotic susceptibility was evaluated in each of the blood culture samples, thus, the cost of materials both for kit and antibiotic susceptibility was $12 \$$ per culture. The mean cost

Table 2. Precipitating factors for cellulitis

\begin{tabular}{l|l}
\hline Characteristics & n (\%) N: 205 \\
\hline Tinea pedis & $62(30.2)$ \\
\hline Trauma & $30(14.6)$ \\
\hline Peripheric vascular disease & $26(12.7)$ \\
\hline Dermatologic disorders & $17(8.3)$ \\
\hline IV/IM injection history & $12(5.8)$ \\
\hline Morbid obesity & $2(1)$ \\
\hline Insect bite & $2(1)$ \\
\hline Thorn prick & $1(0.5)$ \\
\hline Zona disease & $1(0.5)$ \\
\hline Burn & $1(0.5)$ \\
\hline Unknown & $51(24.9)$ \\
\hline IV: Intravenous, IM: Intramuscular &
\end{tabular}

Table 3. Positive culture results of the patients

\begin{tabular}{|c|c|}
\hline $\begin{array}{l}\text { Positive wound culture results } \\
(\mathrm{n}=29)\end{array}$ & Positive blood culture results $(n=7)$ \\
\hline MSSA $(n=18)$ & Beta-hemolytic streptococci $(n=4)$ \\
\hline $\begin{array}{l}\text { Pseudomonas aeruginosa } \\
(\mathrm{n}=3)\end{array}$ & MSSA $(n=2)$ \\
\hline Klebsiella spp. $(\mathrm{n}=3)$ & Serratia marcescens $(n=1)$ \\
\hline MRSA $(n=1)$ & - \\
\hline Aeromonas hydrophila $(\mathrm{n}=1)$ & - \\
\hline Streptococcus pyogenes $(\mathrm{n}=1)$ & - \\
\hline Morganella morganii $(\mathrm{n}=1)$ & - \\
\hline Enterococcus faecalis $(\mathrm{n}=1)$ & - \\
\hline
\end{tabular}


of each patient was $2.3 \times 2.6 \$$. The mean cost of a patient with positive growth and also CNS was $2.3 \times 12 \$$. The total hospital cost of unnecessary blood cultures was 1063.3\$.

\section{Discussion}

Blood cultures were obtained from more than half of the patients $(56.9 \%, 464$ out of 816$)$ admitted to our hospital with SSTIs. A mean of 2.3 cultures per patient were performed in 205 patients included in the study and only seven (3.4\%) had a positive result. Blood cultures were positive in less than $5 \%$ of cases with cellulitis in the previous studies ${ }^{[8]}$. Therefore, current guidelines do not recommend routine blood culture. However, it is strongly recommended in patients with malignancy on chemotherapy, neutropenia, severe cell-mediated immunodeficiency, and immersion injuries ${ }^{[6]}$. Only eight out of 205 cases in this study met at least one of those criteria and two (25\%) had positive blood cultures. Blood cultures were obtained from all the patients whether they had systemic symptoms such as fever and hypotension or not. The total hospital cost of unnecessary blood cultures was 1063.3\$.

In daily clinical practice, clinicians most commonly prefer to differentiate complicated from uncomplicated SSTIs for IV antibiotherapy and for hospitalization. Complicated SSTIs involve deep layers of the skin and patients commonly have underlying co-morbid diseases, receive IV antibiotics or require surgical interventions ${ }^{[9]}$. Some parameters that are not definitive have been used to determine the severity of SSTIs and for considering hospitalization which are fever, head and hand involvement, size of the lesion over $9 \%$ of the body surface and signs or symptoms such as bullae or rapid progression ${ }^{[10]}$. All the patients in this study had at least one of these findings.

Fever is one of the important symptoms in SSTIs and 53.2\% of patients had fever. Obtaining blood culture has been found to be essential particularly in patients with systemic symptoms such as fever ${ }^{[3]}$. Blood cultures have been recommended in patients with signs of sepsis such as fever and tachycardia. However, fever and the other clinical signs have not been suggested to be used for predicting optimum time for blood culture according to the recent guidelines ${ }^{[6]}$.

Implementation of blood cultures are still challenging in this patient population. In a retrospective study, importance of blood culture was assessed and a significant microorganism was isolated in only $2 \%$ of cases ${ }^{[8]}$. In this study, a total of 463 blood cultures were drawn from 205 patients with SSTls. The bacteremia rate was $3.4 \%$ and treatment was changed according to blood culture results in two out of seven patients. There were very low yield of blood culture, therefore, it seems that blood cultures do not frequently affect the patient management. On the other hand, false positive results lead to additional financial cost, unnecessary antibiotic use, and longer hospital stay ${ }^{[11]}$. The contamination rate was $10 \%$ and it was found to be higher than in the previous studies ${ }^{[12]}$. The target contamination rate of blood cultures have been reported to be 2-3\%. However, this rate may vary according to the institutions ${ }^{[12]}$. Prior antibiotic administration is a prevalent factor associated with negative culture results. In this study, 94 (45.9\%) patients had a history of antibiotic use prior to hospitalization. Our setting is a tertiary-care hospital and patients commonly have a history of prior admission to another facility. Thus, they commonly have a history of previously administered antibiotics. The patients hospitalized with SSTIs, particularly cellulitis, were already receiving appropriate empirical therapy active against group A Streptococcus and S. aureus. The most common administered antibiotic was ampicillin/sulbactam. Therefore, blood culture results did not influence the clinicians' decision. However, there was a serious handicap. All of these cases were complicated and delay in appropriate therapy might lead to a severe disease such as sepsis. The characteristics of the lesion is considerably important whether it is complicated or not. If the lesion is purulent, the abscess material should be cultured to detect the causative agent. In this case, obtaining abscess culture could be beneficial for early and effective medical management. Abscess cultures were positive in half of the patients who presented with cellulitis and abscess while treatment was changed according to wound culture results in 17\% of these. The low positive and high contamination rates of blood cultures may also cause increased length of hospital stay and hospital cost. The culture growth signal from the contaminated cultures may lead to unnecessary treatment at least three days before the culture result.

The most common pathogens isolated from the blood cultures were beta-hemolytic streptococci $(n=4)$ and MSSA $(n=2)$, compatible with the results in the literature ${ }^{[10]}$. $S$. marcescens was isolated in a 72-year-old female without any immunosuppressive condition. She presented with erythema, warmth and swelling on her abdominal wall. She had no trauma history and was treated with a third-generation cephalosporin. S. marcescens is a rare cause of cellulitis. It usually causes an opportunistic infection and is associated with underlying predisposing factors ${ }^{[13]}$.

Risk factors related to SSTls are old age, severe underlying disease (e.g., diabetes mellitus), immunodeficiency and vascular insufficiency ${ }^{[10]}$. Diabetes is an important predisposing factor particularly in patients with complicated SSTIs and 64 out of the 205 patients had diabetes. The lower extremities were found the most frequent location $(>70 \%)$. The lower extremities are already under risk for trauma and other predisposing factors such as tinea pedis increases the likelihood of SSTIs ${ }^{[10]}$. Presence of tinea pedis has been found to be a moderate predictive factor 
for SSTIs. Tinea pedis was the most common precipitating factor $(n=62)$ in our study.

This study had some limitations. First, since it was a retrospective study, we might have missed some cases because of limited medical records and wrong ICD codes. Second, almost half of the patients had a history of antibiotic use before admission and also, 29.8\% of patients had received at least one dose of antibiotics before obtaining blood culture. Third, the patients were not evaluated in terms of healthcare-associated SSTIs. The last one is lack of hospital admission criteria. Despite these limitations, the most important finding of this study was extremely low bacteremia incidence in patients admitted to a tertiary care hospital with SSTIs. To our knowledge, this is the first analysis from Turkey to evaluate the blood cultures in SSTIs.

\section{Conclusion}

As a conclusion, since identification of the causative microorganism is not often possible, it may be better to treat patients empirically without additional laboratory tests and hospital charge. We should avoid performing unnecessary blood cultures in patients with cellulitis because of a lack of benefit and no contribution to patient management.

\section{Ethics}

Ethics Committee Approval: Ethics Committee approval was obtained from the Ondokuz Mayis University Medical Faculty Hospital Ethical Council (Decision number: B.30.2.0DM.0.20.08/1348).

Informed Consent: No need for consent form.

Peer-review: Externally and internally peer-reviewed.

Financial Disclosure: The author declared that this study received no financial support.

\section{References}

1. Raff AB, Kroshinsky D. Cellulitis: A Review. JAMA. 2016;16:325-37.

2. Ray GT, Suaya JA, Baxter R. Incidence, microbiology, and patient characteristics of skin and soft-tissue infections in a U.S. population: a retrospective population-based study. BMC Infect Dis. 2013;13:252.

3. Dryden MS. Complicated skin and soft tissue infection. J Antimicrob Chemother. 2010;65:35-44.

4. Zhao C, Liu Y, Zhao M, Liu Y, Yu Y, Chen H, Sun Q, Chen H, Jiang W, Liu Y, Han $\mathrm{S}, \mathrm{Xu}$ Y, Chen M, Cao B, Wang H. Characterization of community acquired Staphylococcus aureus associated with skin and soft tissue infection in Beijing: high prevalence of PVL+ ST398. PLoS One. 2012;7:e38577.

5. Malone JR, Durica SR, Thompson DM, Bogie A, Naifeh M. Blood cultures in the evaluation of uncomplicated skin and soft tissue infections. Pediatrics. 2013;132:454-9.

6. Stevens DL, Bisno AL, Chambers HF, Dellinger EP, Goldstein EJ, Gorbach SL, Hirschmann JV, Kaplan SL, Montoya JG, Wade JC; Infectious Diseases Society of America. Practice guidelines for the diagnosis and management of skin and soft tissue infections: 2014 update by the Infectious Diseases Society of America. Clin Infect Dis. 2014;59:10-52.

7. Murray PR, Masur H. Current approaches to the diagnosis of bacterial and fungal bloodstream infections in the intensive care unit. Crit Care Med. 2012;40:3277-82.

8. Perl B, Gottehrer NP, Raveh D, Schlesinger Y, Rudensky B, Yinnon AM. Costeffectiveness of blood cultures for adult patients with cellulitis. Clin Infect Dis. 1999;29:1483-8.

9. Garau J, Ostermann H, Medina J, Avila M, McBride K, Blasi F; REACH study group. Current management of patients hospitalized with complicated skin and soft tissue infections across Europe (2010-2011): assessment of clinical practice patterns and real-life effectiveness of antibiotics from the REACH study. Clin Microbiol Infect. 2013;19:377-85.

10. Ki V, Rotstein C. Bacterial skin and soft tissue infections in adults: A review of their epidemiology, pathogenesis, diagnosis, treatment and site of care. Can J Infect Dis Med Microbiol. 2008;19:173-84.

11. Shapiro NI, Wolfe RE, Wright SB, Moore R, Bates DW. Who needs a blood culture? A prospectively derived and validated prediction rule. J Emerg Med. 2008;35:255-64.

12. Hall KK, Lyman JA. Updated review of blood culture contamination. Clin Microbiol Rev. 2006;19:788-802.

13. Veraldi S, Nazzaro G. Skin ulcers caused by Serratia marcescens: three cases and a review of the literature. Eur J Dermatol. 2016;26:373-6. 